\title{
Musculoskeletal Findings, Connective and Soft Tissue Findings Sponsor-Defined Identifier
}

National Cancer Institute

\section{Source}

National Cancer Institute. Musculoskeletal Findings, Connective and Soft Tissue Findings

Sponsor-Defined Identifier. NCI Thesaurus. Code C162198.

One or more sponsor defined characters used to identify, name, or characterize the musculoskeletal finding. 